The European dilemma: Evaluating the implications of Europa League participation on English Premier League clubs.

Authors:

Mr. Adam Cox

Address: University of Portsmouth, Portsmouth Business School, Portland Street, Portsmouth, PO1 3DE, United Kingdom

Tel: +44 (0) 2392-844732

Email: $\underline{\text { adam.cox@port.ac.uk }}$

Dr. Sarah Gilmore,

Address: University of Portsmouth, Portsmouth Business School, Portland Street, Portsmouth, PO1 3DE, United Kingdom

Tel: $+44(0)$ 2392-844153

Email: sarah.gilmore@port.ac.uk

Mr. Alan Graham ${ }^{1}$

Address: University of Portsmouth, Portsmouth Business School, Portland Street, Portsmouth, PO1 3DE, United Kingdom

Tel: +44 (0) 2392-844795

Email: alan.graham@port.ac.uk

Disclosure Statement:

The above authors disclose that there are no relationships that could be viewed as presenting a potential conflict of interest.

${ }^{1}$ Corresponding author, Email: alan.graham@port.ac.uk 


\title{
The European dilemma: Evaluating the implications of UEFA Europa League participation on English Premier League clubs.
}

\begin{abstract}
For clubs qualifying for the UEFA Europa League, participation generates a series of tensions. Football's European governing body, UEFA, has provided generous financial rewards for those clubs, but with qualification comes additional pressures on playing squads which are often less able to deal with the performative demands of an extra competition, as they generally possess fewer financial resources compared with teams that regularly gain UEFA Champions League qualification. This paper evaluates these conflicting tensions.

The study takes a detailed quantitative analysis of the associated costs and benefits for four Premier League clubs that have repeatedly participated in the Europa League over an eight seasons. The analysis demonstrates a positive financial benefit of participation, but this is only significant if the club progresses to the later stages of the competition and has a robust playing squad. Participation may also have further less tangible benefits.

This research fills a gap in a lack of analysis based on reliable empirical data as to the impact of participation in this competition on clubs.
\end{abstract}

Keywords: Europa League, Finance, UEFA, Europeanisation, Management Decision 


\section{Introduction}

There is general consensus that the landscape of European football has undergone profound change since the early 1990s, especially for those clubs operating at the elite levels of the sport at club level. ${ }^{1}$ Those promoting such arguments generally point to the growth of club turnover in major Western European football leagues, the increasing importance of the UEFA Champions League to various 'phases' of 'Europeanisation,' as well as the formation and influence of elite clubs' organisations, such as the G.14. The significance of Europe, and specifically the Champions League, to the changing financial landscape of European football can be seen in yearly commentaries made by commentators on the sport, such as the accountancy firm, Deloitte. Whilst the Deloitte review ${ }^{2}$ of the Premier League and the European 'rich list' accounts for fluctuations in club revenues and financial performance over a yearly period, the discourses concerning the important economic value of the Champions League to those participating in it have remained a consistent feature of these documents over time.

Set against the dominance of the Champions League concerning accounts of the changing face of European football, this paper argues for the inclusion of the Europa league (formerly known as the UEFA Cup until its rebranding in 2009) within such analyses. In particular, we argue that the clubs who qualify for this particular competition are faced with a different set of challenges to those clubs that qualify, and qualify regularly, for the Champions League. These are difficult for clubs to resolve, but are nevertheless consequential for them because they place additional performance and resourcing pressures onto organisations that are variably equipped to meet them. Qualification arguably involves successful clubs re-orienting their teams' priorities given that they will be faced with the task of playing in an additional 
competition whilst also continuing to compete within the Premier League, the two English cup competitions, and ensuring that they are compliant with the UEFA Financial Fair Play regulations. This paper seeks to map out these tensions in more detail and to position them in general terms against discussions concerning the 'Europeanisation' of football, especially in relation to football finances within Europe and those of the Premier League. To assess the impact of Europa League qualification on our sample of Premier League clubs, we deploy quantitative analysis, weighing up the costs and benefits using financial data. Findings show that there are financial benefits for those playing in the Europa League, although when compared with the overall wealth generated by the moneys at stake in the UEFA Champions League and English Premier League, these would not be considered highly lucrative.

\section{The Europa League and the Europeanisation of football}

Although there is no one accepted definition of the term, 'Europeanisation' refers here to the increasingly powerful role played by European-level policy-making on domestic policies and practices as well as the complex interplay between entities representing national interests when arguing for their preferences via processes of negotiation. In this way, the Europeanisation of football can be viewed as a complex relationship between UEFA as the sport's European governing body, acts of 'eventisation' such as the European Championship, Champions League and the UEFA Cup/Europa League, and the media. The interplay of these forces has acted to institutionalise and sediment the legitimacy of UEFA due to the decisive role played by the media in supporting its competitions, whilst simultaneously generating the

income and audiences for them. As argued by Martin, ${ }^{3}$ football's 'mediascapes' and 'financescapes' have become intertwined with the televisual mediascape of football 
now being experienced as a process of Europeanisation with the coverage given to football broadening from an exclusively domestic focus to an increasingly European one. It could be argued that the Europa League has the potential to play a heightened role in the assertion of European football, but as yet its influence here is weak due to the lack of status and rewards associated with the competition, especially when compared to those associated with the Champions League.

Despite an economic downturn and continuing fiscal uncertainty experienced by several EU members, the position of European football is argued by some commentators to be robust, in good health and impervious to a European financial crisis. According to findings by Deloitte, ${ }^{4}$ the top 20 European clubs generated $€ 4.84$ bn in revenue during the $2011 / 12$ season, representing an increase of $10 \%$ on the previous years. This figure is estimated to account for more than a quarter of the European football industry and is expected to grow in the foreseeable future. ${ }^{5}$ One of the main factors behind such statements is the ability of the top four clubs to sustain their competitive presence within the UEFA Champions League, with commentators arguing that the importance of finishing within the top four positions in the English Premier League in order to qualify for this competition cannot be underestimated. As noted by Kennedy and Kennedy, ${ }^{6}$ the Champions League is now confirmed as the ultimate global club competition attracting a worldwide audience of more than four billion viewers per season, with viewing figures for the final surpassing those of the NFL's Superbowl, boosting the status of UEFA and the Europeanisation process. This status is further enhanced through the moneys it generates for the Champions League as UEFA receives over $€ 500$ million in broadcasting and sponsorship income. These sums have been increased by the recent contract with new entrants to the UK broadcasting market, BT Sport, which paid $£ 897$ million for a three year deal to 
broadcast live Champions League and Europa Cup matches. ${ }^{7}$ Participating Premier League clubs did less well in the 2012/2013 CL competition, earning between $€ 28-35$ million each from TV and bonus income, ${ }^{8}$ although, the moneys attained by the Champions League finalists dwarfed these figures. Tournament winners, Bayern Munich, and runners up Borussia Dortmund earned $€ 55$ million and $€ 54$ million respectively. At this juncture it is pertinent to note that this kind of lavish remuneration and attendant media focus has rarely, if ever, been associated with the UEFA Cup or the Europa League and whilst the additional moneys accruing from the 2013 BT Sport deal might enrich the Europa League, there is currently no sign that this will follow. The 2012/2013 Europa League finalists, SL Benfica and Chelsea FC, won $€ 5.7$ and $€ 10.7$ million respectively during the same season. ${ }^{9}$

Set against this picture, other analyses of the financial health of the European football and the Premier League offer a less certain account. ${ }^{10}$ The widening participation of clubs in Europe has resulted in some clubs spending increasing amounts of money on transfer fees and wages. This has led to a sense of clubs 'spiralling out of control' as new owners seek to outbid other high spending clubs ${ }^{11}$ and the threat of bankruptcy hangs over a number of clubs. Several studies highlight the size of the financial instability currently characterising clubs and leagues ${ }^{12}$ and Cuttler succinctly describes the strains experienced by clubs faced with contemporary performance challenges thus:

'...the face of European football is contorted by the strain experienced by clubs attempting to remain on a financial tightrope which is constantly being yanked by their competitors. It's as simple as this. Clubs need to be successful if they are to prosper. But to be competitive they have to invest in player transfers and wages which, all too often, they are unable to afford. For all but the biggest clubs, every season represents a gamble. For those whose gambles do not pay off the result is relegation, reduced income and the prospect of severe financial difficulty. It's a kind of financial Russian roulette'. ${ }^{13}$ 
Currently, the Premier League generates the highest levels of income but also the highest levels of debt, standing at $£ 2.6$ billion in $2011 / 12$. Whilst a new TV deal could assist clubs in eradicating their debts, doing this would require any rise in player salaries to be kept to a respectable level ${ }^{14}$ and given the tensions depicted by Cuttler, and historical responses of clubs to increases in income originating from enhanced TV moneys, it is questionable as to whether such fiscal prudence would be forthcoming.

According to the UEFA Executive Committee, ${ }^{15}$ the issue of financial instability has created difficult market conditions for clubs in Europe and can negatively impact their revenue generating ability and viability as a going concern. This urged UEFA to introduce the 'Financial Fair Play Rules' (FFPR), ${ }^{16}$ the scope of which was to introduce more discipline and rationality of clubs' finances to rebalance competition by enhancing long-term financial stability in European club football ${ }^{17}$ and with a view that in the longer term, clubs carrying a large debt loading will reach a breakeven position. It is against this picture of local fiscal instability and supranational attempts to instigate better systems of financial governance that these tensions concerning the Europa League are played out.

\section{The Europa League: tensions and dilemmas}

For many clubs that qualify for the Europa League, attaining this status is a cause for celebration because it can often mark the highest achievement for the organisation in its history. Participation in the competition is often perceived and promoted as a mark of success for the club's fans, Board members, employees, and investors. For managers, players and backroom staff, competing in the Europa League is a 
significant career achievement and as such it can mark the pinnacle of many professional careers. For some supporters it is an opportunity for a 'European Tour': following the team overseas to play in new locations and providing new opponents to observe at home. However, the competition raises a number of tensions and challenges for participating clubs, many of which have their origins in the increasingly precarious nature of football club finances.

In 2009 the UEFA Cup was re-branded, as witnessed in the change in title. The group stage of the competition was expanded from 8 to 12 groups of four teams. The top two teams from each group joined in the Round of 32 by the eight clubs finishing third in their UEFA Champions League group. This expansion of the League offered European football to a wider group of clubs and nations. To this end, the group stage of the 2011/12 Europa League contained clubs from 24 different nations. In $2010 / 11$ the Europa League distributed $€ 150 \mathrm{~m}$ between the 56 clubs reaching at least the group stage of the competition. According to Deloitte, ${ }^{18}$ the rebranding of the League, including the collective selling of repackaged broadcast rights to cover more of the competition and the introduction of a new presenting sponsor, has seen the 2010/11 Europa League distributions increase almost fourfold from the $€ 39 \mathrm{~m}$ distributed in the last season of the UEFA Cup, 2008/09. For individual clubs, the increased distributions meant that reaching the group stage of the Europa League in $2010 / 11$ was worth at least $€ 1.1 \mathrm{~m}$, compared with $€ 0.2 \mathrm{~m}$ two years earlier in the UEFA Cup. For those countries with high value broadcast rights, the market pool distribution of earnings can be significant, as witnessed by losing semi-finalist, Villarreal, who managed to earn $€ 9$ million in distributions which in the 2010/11 season was the highest of any Europa League club, including the winners FC Porto. ${ }^{19}$ In May 2013, UEFA announced that the winners of the 2015 Europa League would 
qualify for the Champions League for the following season. ${ }^{20}$ No further changes were made with regards to domestic qualification rules.

The implications of Europa League participation for Premier League clubs need to be set within the context of English football's financial present and near future; clubs have been struggling (and have often failed) to avoid financial crises for a number of years. ${ }^{21}$ Participating in the EL could potentially offer the possibility of generating additional revenues. For example, in the 2009/10 Europa League Fulham FC generated $€ 10.6$ million. ${ }^{22}$ Although the team lost in the final to Atletico Madrid, the sums generated constituted $16 \%$ of the club's revenue for that season. ${ }^{23}$ Participation in European competitions should take place whilst following stringent set of rules regarding the control of relevant costs as part of a breakeven requirement set by UEFA. It is therefore important for clubs to ensure that they do not breach Financial Fair Play regulations and it could be envisaged that clubs may not want to stretch themselves excessively, even if that means a failure to meet the qualification standard needed to enter the Europa League.

Other benefits for participating in the EL lie in the experience it gives of playing European competition. For clubs, managers and teams with aspirations to playing in the CL, this is highly valuable. This was seen in the case of Zenit St Petersburg whose participation in the UEFA Cup and EL gave them valuable experience of competing in European competitions. This helped them progress through the 2011/12 Champions League group stage into the knockout rounds. Similarly, Shakhtar Donetsk's experiences in this competition assisted them in qualifying for the quarter-finals of the 2010/11 Champions League before losing to the eventual winners, FC Barcelona. ${ }^{24}$ Successful managers competing in the Europa 
League have been vocal in their support for the competition within the Premier League, as witnessed in comments made by managers such as Rafa Benitez and Andres Villas Boas, who were both winners. This does not always find a receptive audience with players who seek 'Tuesday/Wednesday night football' of the Champions League and perceive the Europa League as being a second-best competition.

Several UK broadsheet commentators concur with their view and make additional points as to the benefits of playing European football, for example, Taylor $^{25}$ and Turner. ${ }^{26}$ There are long-standing problems and tensions caused by the Europa League persist. Strains on playing squads that have limited strength in depth, compared to some of their Premier and Europa League competitors, make them more vulnerable to potential player injuries. ${ }^{27}$ Additionally, the balancing of Premier League and Europa League commitments can be challenging as managers are frequently tasked with maintaining, if not exceeding, Premier League performance. This results in generating tensions concerning the priority of club objectives and can be particularly acute if the distributions of revenue from domestic leagues are substantial. In the case of the Premier League, finishing one place higher at the end of the season was worth approximately $£ 0.8$ million in the $2012 / 13$ season. ${ }^{28}$ Clubs seeking to enter the Champions League via a top four finish, or to avoid relegation from the Premier League, have to assess the value of achieving such aims alongside the value of progressing in the Europa League. These kinds of tensions exert a significant performance pressure for those clubs competing in the Europa League all season as they usually have less strength in their playing squads as well as generally having reduced fiscal resources in comparison to the clubs competing in the Champions League. 
A concern frequently voiced in English football is a perceived lack of competition within all but the largest clubs. Gratton referred to the situation created by a lack of 'competitive balance' whereupon fans lose interest in matches when they believe that the outcome of a match is shifted too far away from one team. ${ }^{29}$ This state of affairs, if it is indeed prevalent, could have a positive effect on Europa League as it may mean that the competition is seen as more open and less likely to be dominated by a few of the largest and richest clubs, which would tend to be participating in the more lucrative Champions League competition. Finally, whilst managers and players might find the benefits of strong performances in the Europa League to be highly rewarding, their (possible) departure to other teams could be detrimental to team performance in the following season.

Given these multiple benefits and problems with regards to Europa League qualification and prioritising it (or not), it is timely to assess its value. The following sections contain quantitative analyses of some of the key tensions previously outlined. It will conclude with an analysis of the measurable quantifiable benefits and costs arising from participation in a representative sample of English clubs.

\section{Method}

This paper seeks to measure the impact of participation within this competition on a number of English Premier League clubs using available, reliable data. This involves a quantitative methodology, weighing up the costs and benefits, using financial information and other 'soft' information that can be reconciled as a potential financial value. The analysis compares the benefit (cost) of participation in the Europa League with the cost (benefit) of not participating. The authors note that the relationships between participation and a financial cost or benefit must therefore be by correlation 
rather than measuring causality. As such, provides an important insight not yet provided in an academic setting, to our knowledge.

A detailed analysis is carried out on a small number of Premier League clubs that have entered the Europa League competition over eight seasons, from 2005/06, and measures the key costs and benefits associated with participation in it. To achieve this, the focus is on the following four English Premier League Clubs: Aston Villa FC, Everton FC, Fulham FC and Newcastle United FC. The criteria used to select clubs were that:

- Each had appeared in the Europa League competition more than once in the prior seven seasons. Observing information in the state of participation compared to nonparticipation requires a number of observations in each state. Aston Villa appeared in three seasons, 2008/9 to 2010/11 inclusive. Everton appeared in three seasons, 2007/8 to 2009/10 inclusive. Fulham appeared twice, in 2009/10 and 2011/12. Newcastle United appeared twice, in 2006/7 and 2012/13.

- For each club, qualification for the Europa League was considered to be a realistic goal, rather than a 'consolation prize' for failure to achieve qualification for the more lucrative Champions League. Therefore, clubs that had taken part in the Europa League in recent seasons, but with a greater success in terms of Premier League position, such as Chelsea, Tottenham Hotspur and Liverpool, were excluded from the sample, as the authors judged that these clubs would have more likely targeted Champions League qualification as their aim, rather than Europa League participation. 
In order to provide a quantitative measure of the implications of Europa League, various cost/ benefit metrics are produced which cover relevant indicators. The indicators and their data sources are as follows:

- Prize moneys are awarded for participation in the Europa League competition. This includes share of broadcasting moneys taken from the UEFA Financial Report. ${ }^{30}$ Prize moneys are awarded for league position in the PL. ${ }^{31}$

- Match day revenues are measured by stadium attendance figures from home games in the Europa competition taken from UEFA match reports. Domestic league attendance figures are taken from respective editions of the Sky Sport Football Yearbook (Rollin, 2005 - 2012) released annually. ${ }^{32}$

- Annual disaggregated revenue information, including commercial revenue, is taken from respective club annual reports provided by Companies House. ${ }^{33}$

- Club wage expenditures and player transfer fees are both measured annually by Deloitte (Various years). ${ }^{34}$

Additionally, due consideration is made of the non-quantifiable costs and benefits, such as the possible effects on the existing playing squad, the attraction of player and managerial talent and perceptions of the status achieved by participation in a European competition. These all form part of the 'tensions' outlined previously.

The research approach also addresses the issue of whether the clubs concerned are able to leverage the potential commercial spin-offs associated with increased global exposure to their benefit. 


\section{Results and analysis}

In the following analysis, a number of measures have been used to assess the 'success', or otherwise, of Europa League qualification.

\section{Prize money and UEFA distributions}

Table 1 lists prize money obtained in respect of Europa League competitions (UEFA, 2013). ${ }^{35}$ It shows that Fulham have been successful in achieving moneys in excess of $£ 11 \mathrm{~m}$, which was largely the result of reaching the final of the competition in the 2009/10 season. In comparison, Aston Villa has gained relatively small amounts, losing in the preliminary play-off stages in two of the three seasons in which they qualified.

\section{Place Table 1 here.}

\section{Premier League position distribution money}

It has often been suggested, albeit anecdotally, that the extra demands imposed by clubs' participation in the Europa League, such as the increased risk of injuries to already stretched playing squads, has an adverse effect on their Premier League performance in the seasons of Europa League competition. Table 2 shows the change in league position, by comparing the average league position in the seasons of Europa League participation with those of the seasons immediately prior to qualification for it (allowing also for the number of years of participation).

Place Table 2 here. 
The evidence suggests that league performance suffers when a club plays in the Europa League, with the notable exception of Everton. These effects were particularly marked in the case of Newcastle United, where the club's league position worsened by 11 places in the 2012/13 season and 6 places in the 2006/07 season. This supports the findings of Verheijen, ${ }^{36}$ showing that Europa League games played on a Thursday followed by a league game on Sunday costs clubs an average of 0.41 league points per game. The points are lost as a result of the detrimental impact player fatigue has on clubs' performances.

A further analysis of the effects of Europa League participation on league performance is achieved by considering the total number of Europa League matches played by each of our sample clubs during the league season and calculating the total points deficit (using Verheijen's above figure of 0.41 points per game). At the end of the season concerned, the effect on the clubs' final league positions, had they not suffered this points deficit, can be calculated and a monetary prize amount lost is reached from the data, shown in the Table 3 . The results identify a detrimental change in financial reward for all clubs.

\section{Place Table 3 here.}

\section{Match day revenues}

Attendance figures for Europa League matches, including qualifying matches, are used to calculate gross match day income figures. Season ticket holders generally do not get a free entry to cup competition matches, so this would be marginal income above that obtained from season ticket sales, shown in Table 4. An average admission ticket price of $£ 22$ has been assumed, ${ }^{37}$ which is approximately $20 \%$ lower 
than the average ticket price charged for Premier League matches, as clubs often use a pricing strategy which targets these matches to try to maximise attendances. This admission price is therefore a conservative estimate. It should be mentioned here that although much of a football club's costs are fixed in nature, for example, overheads such rent, depreciation, utilities, basic wages and salaries etc., there are also marginal costs involved in the staging of a match. These would include the costs of policing and stewarding, for instance, as well as any player bonuses contingent upon the result. These are multi-varied and thus difficult to measure, so attendance revenue is used as an approximate value.

\section{Place Table 4 here.}

The table shows that the marginal revenue increases from participating in the Europa League for the four selected clubs vary from approximately $£ 5$ million to $£ 10$ million, which represents a significant increase in revenue, but which is somewhat dwarfed by the levels of money, particularly from broadcasting, from participating in the Premier League and UEFA Champions League.

If a club's league form suffers, this may have a direct negative effect on league attendances. Table 5 compares average Premier League attendances in the seasons of Europa League competition with those in the seasons immediately prior to

qualification. ${ }^{38}$ A monetary value has been derived, which assumes that the admission price is $£ 28.30$ based upon a Premier League minimum adult price, ${ }^{39}$ then multiplied over the 19 home games of the Premier League season. This does not take into account that much of the match day revenue would be in the form of prepaid season tickets, so the reported monetary effect is over-estimated. In balance, spectators (including those who have prepaid) spend on items such as match day programmes, merchandising, food and drink, so there is likely to be a drop in these sources of 
sundry revenue when attendances fall. The figures in the table below have therefore assumed that the above effects counterbalance each other.

\section{Place Table 5 here.}

This table shows that there is an insignificant fall in average Premier League attendances of less than $1 \%$ for three of the four clubs in the season of participation in the Europa League. The largest fall was 3.8\% in the case of Aston Villa, but that still represents a drop in estimated gate money of less than $£ 1 \mathrm{~m}$.

\section{Player expenditure}

The number of players used in a season is expected to be linked to the number of games played. The more matches played, the greater the risk of injuries, putting playing squads under additional pressure. In a study of European leagues, Verheijen ${ }^{40}$ found that shorter recovery times between games resulted in a decrease in a club's performance and an increase in injury rates. In recent seasons, there has been a growing trend for Premier League clubs to use cup matches as a means of blooding new talent and resting key players for the potentially more lucrative Premier League matches. Therefore, in order to measure the possible effect that Europa League participation has had on a squad, the number of players used in Premier League games in a season of Europa League participation has been compared with that when there were no such extra European demands, shown in Table 6.

\section{Place Table 6 here.}

This shows that, with the exception of Fulham, participation in the Europa League has resulted in more players being used for the Premier League. In the case of Newcastle 
United in 2012/13, six more players were used compared with the following season, as injuries took their toll on the squad.

An analysis of transfer activity at the four clubs during Europa League participation shows that in each case annual net transfer spending (the cost of buying players less sale proceeds from player sold) was greater than in seasons of nonEuropa League participation, shown in Table 7. In the cases of Aston Villa and Newcastle the difference between net transfer spending on players was particularly marked in the seasons of EL participation compared with non-EL participation with annualised differences of $£ 18.1 \mathrm{~m}$ and $£ 17.3 \mathrm{~m}$ for the two clubs respectively.

\section{Place Table 7 here}

This supports the argument that Europa League participation puts significant strains on the playing squad and that one of way addressing this is to bolster the pool of available players. It could also be argued that clubs view Europa League participation as an attractive 'pull' to entice new talent to join the club. Similarly, the players themselves may see it as a sign that a club is ambitious and progressive and therefore are attracted to it.

\section{Wage Costs}

The total annual wage costs for each club along with the percentage of turnover are shown in Table $8 .^{41}$ On average, club revenue is higher for all clubs during years of participation in the Europa League. With the exception of Newcastle, all clubs increased their wage costs during the same seasons, without compensating for inflation.

\section{Place Table 8 here}


The increase in wage costs, with the exception of Aston Villa, is a smaller proportional increase than the rise in revenue. This shows a correlation between Europa League participation and spending a smaller proportion of revenue on wages, from $72 \%$ to $63 \%$ in the case of Everton. Aston Villa, however, increased the average annual proportion of revenue spent on wages during the seasons participating in the Europa League from $81 \%$ to $92 \%$. Aston Villa's wage costs increased to $103 \%$ of revenue during the 2010/11 season showing a high level of spending during Europa League participation.

\section{Commercial activities}

Commercial revenues may well be enhanced by appearance on an international stage. The evidence from the four English clubs considered appears that this is not the case, as shown in Table 9 (compiled using annual financial statements, retrieved from Companies House), ${ }^{42}$ where for three of the four clubs commercial revenues as a proportion of total revenues fell in the years of EL participation. It should be noted, however, that commercial revenues can be measured and presented by clubs in different ways so direct comparisons between clubs do not necessarily give a clear picture. The description of commercial revenue differs for each club and is shown in Table 9.

\section{Place Table 9 here.}

The data show that the clubs' average commercial revenues in the seasons of Europa League participation were lower as a percentage of total revenue than in seasons of non-participation, with the exception of Newcastle, for which only one year of accounts was obtainable. This suggests that clubs are not making the most of the opportunity provided from showcasing their talent in Europe in order to leverage 
more income for future investment in better players and facilities. Any such initiative would need to consider the effect on the clubs' supporter base, as recent research by Kennedy and Kennedy suggests that commercialisation can both increase supporters' interest with their club, as well as equally create a sense of disillusionment in others. ${ }^{43}$ It is noted by way of comparison that the equivalent percentages of commercial revenue for the consistent Champions League participants and recent winners, such as Manchester United and Chelsea, is typically higher at about 30\%.

\section{Overall quantifiable cost/benefits}

Summarising the presented quantitative data gives the following positions for each club, shown in Table 10. It should be noted that net transfer spending is excluded from this table, as transfer spending is a cost which is capitalised by clubs in their balance sheet and then amortised through the income statement, rather than written off immediately against income. Also, given the lack of a clear relationship between wage costs and Europa League participation (from Table 8), these costs are also excluded from the table. There is no evidence to suggest that wages costs were a result of, or a determinant of, Europa League participation. Finally, given the wide scope that clubs have in deciding how much of their revenues should be designated as originating from commercial sources (Table 9) and therefore the lack of consistency in comparing it between clubs, these amounts have also been excluded from the overall quantitative position in Table 10.

\section{Place Table 10 here}

This shows that there is a net benefit in category one for all clubs which ranges from over $£ 2$ million in the case of Aston Villa, to almost $£ 15$ million for Fulham. The 
benefits are particularly marked for clubs that progress to the latter stages of the Europa League competition, hence the large prize money received by Fulham after reaching the final in $2009 / 10$. Despite a fall in domestic league form during the 2012/13 season, Newcastle has an $£ 8$ million positive impact during seasons of participation in the Europa League.

The evidence presented here suggests that participation in the Europa League can have a positive but small financial impact on a club if the expenditure on players is closely constrained. Further, the cost needed to build a competitive squad for the Europa League may increase for clubs that are positioned further down the Premier League table.

\section{Considerations for further research}

There are the other possible spin-offs that are not captured in the analysis. These may include an increased ability to attract and retain top talent or brand awareness. Further, there are effects that may have a knock on impact over a period of time not accounted for here. Also transfer spending on players is not usually treated as a oneoff overhead or revenue cost, but new player registrations are instead capitalised in the balance sheet as intangible assets and amortised through the income statement over the duration of the contract. Hence the cost is typically spread over several years and so is not included in the overall cost/benefit summary.

Additional marginal costs borne by clubs would include, for example, medical costs, win/loyalty bonuses payable to players, policing costs, insurance, travel etc. Sundry income items, such as sales from merchandising, refreshments etc. directly 
related to Europa League matches have been assumed to match marginal costs associated with matches and have therefore also been ignored for the purposes of this analysis.

\section{Conclusions and further research}

This paper uses financial information to address some of the key tensions faced by Premier League clubs who play in the Europa League. The relationship of the measurements analysed between Europa League participation and non- participation reflects a correlation, not causality. This paper shows evidence that on average there is some change in the observed variables between two states. Evidence that participation in the Europa League has caused these observed changes requires further investigation. Results show that participation in the Europa League can return a small positive financial benefit. However, the benefit is highly sensitive to the cost of playing talent, in transfer fees and wages. Whilst this contributes to the debate concerning the problems and benefits accruing to clubs which participate in the Europa League, there are a number of areas where further research is needed. Finally, whilst the Europa League makes a contribution towards processes of Europeanisation of football, that contribution is currently modest and will be likely to remain such given the generally slight benefits that accrue to those clubs that participate in it. Given these findings, and the caveats made for further research, there is arguably a case to be made for UEFA reviewing the moneys it provides for Europa League participants both in terms of assisting in the resolution of some of the tensions outlined here and as a means of further establishing their presence within the domestic competitions of its member countries. 


\section{Tables}

Table 1. Europa League prize money from 2006/07.

\begin{tabular}{|l|l|}
\hline Club & $\begin{array}{l}\text { Prize money £’000 - } \\
\text { translated at Euro/£ rate } \\
28 / 11 / 13,{ }^{44}\end{array}$ \\
\hline Aston Villa & 322 \\
\hline Everton & 4,339 \\
\hline Fulham & 11,240 \\
\hline Newcastle & 4,823 \\
\hline
\end{tabular}

Table 2. Premier League positions before and during Europa League participation

\begin{tabular}{|l|l|l|c|}
\hline Club & $\begin{array}{l}\text { League position } \\
\text { pre-qualification } \\
\text { to EL }\end{array}$ & $\begin{array}{l}\text { League position } \\
\text { during EL comp. }\end{array}$ & $\begin{array}{l}\text { Total change in } \\
\text { league position }\end{array}$ \\
\hline Aston Villa & 6 & $\begin{array}{l}7 \text { (average of } 3 \\
\text { seasons) }\end{array}$ & -3 (3 seasons) \\
\hline Everton & 6 & $\begin{array}{l}6 \text { (average of } 3 \\
\text { seasons) }\end{array}$ & 0 (3 seasons) \\
\hline Fulham & 7,8 & 12,9 & -6 (2 seasons) \\
\hline Newcastle & 7,5 & 13,16 & -17 \\
\hline
\end{tabular}

Table 3. Effects on Premier League position by applying average points per game deficit figure.

\begin{tabular}{|l|l|l|l|l|}
\hline Club/Season & $\begin{array}{l}\text { Number of } \\
\text { matches }\end{array}$ & $\begin{array}{l}\text { Points deficit } \\
(@ 0.41 \\
\text { points/game })\end{array}$ & $\begin{array}{l}\text { Effect on final } \\
\text { PL place }\end{array}$ & $\begin{array}{l}\text { Change in league position } \\
\text { money, £'000 (assumes } \\
\text { each place is worth £750K })\end{array}$ \\
\hline Aston Villa & & & & \\
\hline$-2008 / 09$ & 8 & 3.28 & 1 & -750 \\
\hline$-2009 / 10$ & 2 & 0.82 & 0 & 0 \\
\hline$-2010 / 11$ & 2 & 0.82 & 0 & 0 \\
\hline Total & & & & -750 \\
\hline & & & & \\
\hline Everton & & & & 0 \\
\hline$-2007 / 08$ & 10 & 4.1 & 0 & 0 \\
\hline$-2008 / 09$ & 2 & 0.82 & 0 & $-1,500$ \\
\hline$-2009 / 10$ & 10 & 4.1 & 2 & $-1,500$ \\
\hline Total & & & & \\
\hline & & & & $-2,250$ \\
\hline Fulham & & & 3 & -750 \\
\hline$-2009 / 10$ & 16 & 6.56 & & $-3,000$ \\
\hline$-2011 / 12$ & 8 & 3.28 & & \\
\hline Total & & & & \\
\hline & & & & \\
\hline Newcastle & & & & \\
\hline
\end{tabular}




\begin{tabular}{|l|l|l|l|l|}
\hline$-2006 / 07$ & 12 & 4.92 & 1 & -750 \\
\hline$-2012 / 13$ & 14 & 5.74 & 7 & $-5,250$ \\
\hline Total & & & & $-6,000$ \\
\hline
\end{tabular}

Table 4. Match day receipts from Europa League matches.

\begin{tabular}{|l|l|l|l|l|}
\hline Club & $\begin{array}{l}\text { Average EL } \\
\text { attendance }\end{array}$ & $\begin{array}{l}\text { Number of } \\
\text { matches }\end{array}$ & $\begin{array}{l}\text { Aggregate } \\
\text { attendance }\end{array}$ & $\begin{array}{l}\text { Monetary } \\
\text { effect }(£ K)\end{array}$ \\
\hline Aston Villa & 30,400 & 8 & 243,200 & 5,300 \\
\hline Everton & 30,800 & 11 & 338,800 & 7,500 \\
\hline Fulham & 18,600 & 16 & 297,600 & 6,500 \\
\hline Newcastle & 31,800 & 14 & 445,200 & 9,800 \\
\hline
\end{tabular}

Table 5. Premier League average attendances prior and during Europa League competition.

\begin{tabular}{|l|l|l|l|l|}
\hline Club & $\begin{array}{l}\text { Average PL } \\
\text { attendance in } \\
\text { seasons prior } \\
\text { to participation }\end{array}$ & $\begin{array}{l}\text { Average PL } \\
\text { attendance in } \\
\text { seasons of } \\
\text { participation }\end{array}$ & Change (\%) & $\begin{array}{l}\text { Monetary } \\
\text { effect per } \\
\text { annum (£K) }\end{array}$ \\
\hline Aston Villa & 40,029 & 38,526 & -3.8 & -808 \\
\hline Everton & 36,736 & 36,449 & -0.8 & -155 \\
\hline Fulham & 24,689 & 24,601 & -0.4 & -48 \\
\hline Newcastle & 50,984 & 50,602 & -0.7 & -205 \\
\hline
\end{tabular}

Table 6. Change in number of players used in Premier League as a result of Europa league participation.

\begin{tabular}{|l|l|l|l|}
\hline Club & $\begin{array}{l}\text { Number of } \\
\text { players used in } \\
\text { PL in most } \\
\text { recent season of } \\
\text { EL participation }\end{array}$ & $\begin{array}{l}\text { Number of } \\
\text { players used in } \\
\text { PL after most } \\
\text { recent season of } \\
\text { EL participation }\end{array}$ & \\
& 32 & 27 & 5 \\
\hline Aston Villa & 28 & 24 & 4 \\
\hline Everton & 28 & 29 & -1 \\
\hline Fulham & 32 & 26 & 6 \\
\hline Newcastle & & & \\
\hline
\end{tabular}




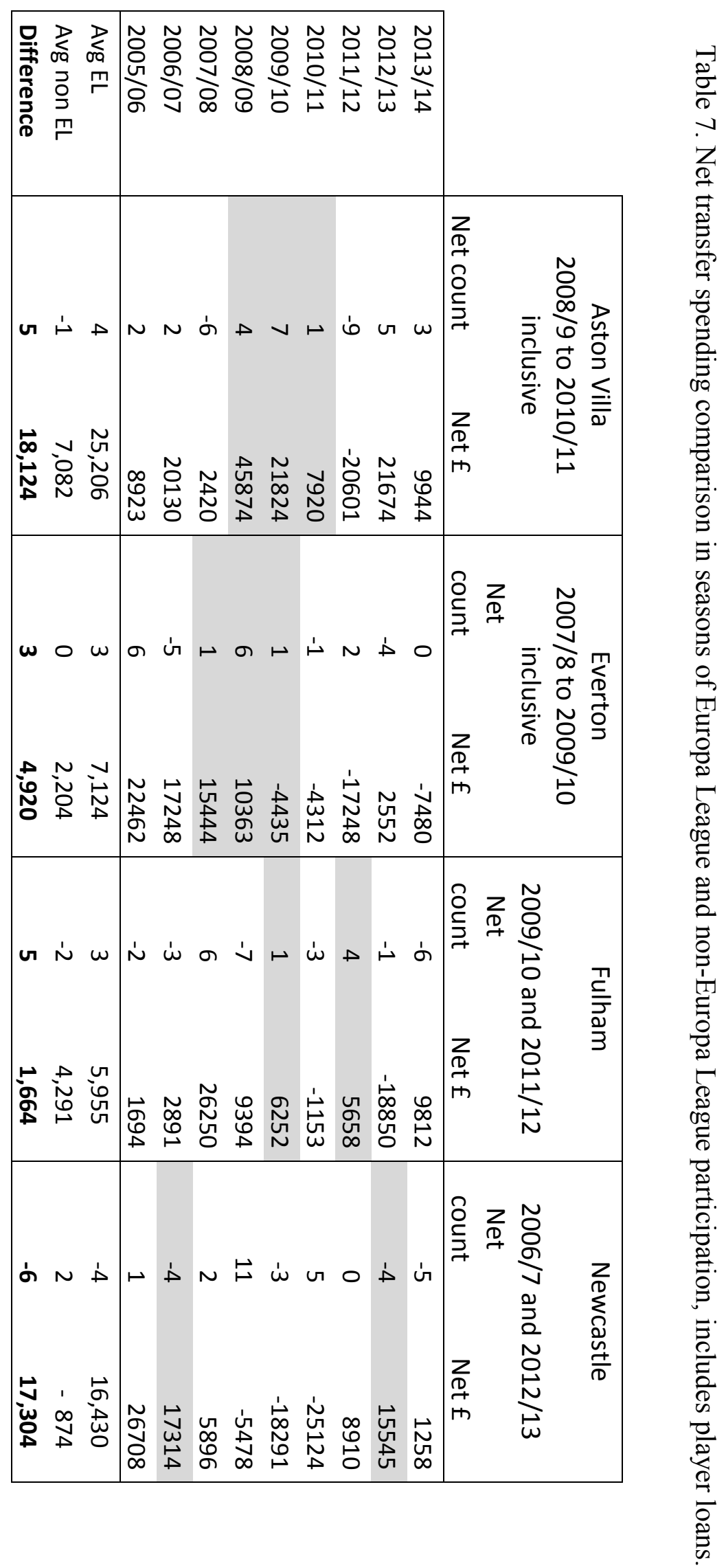




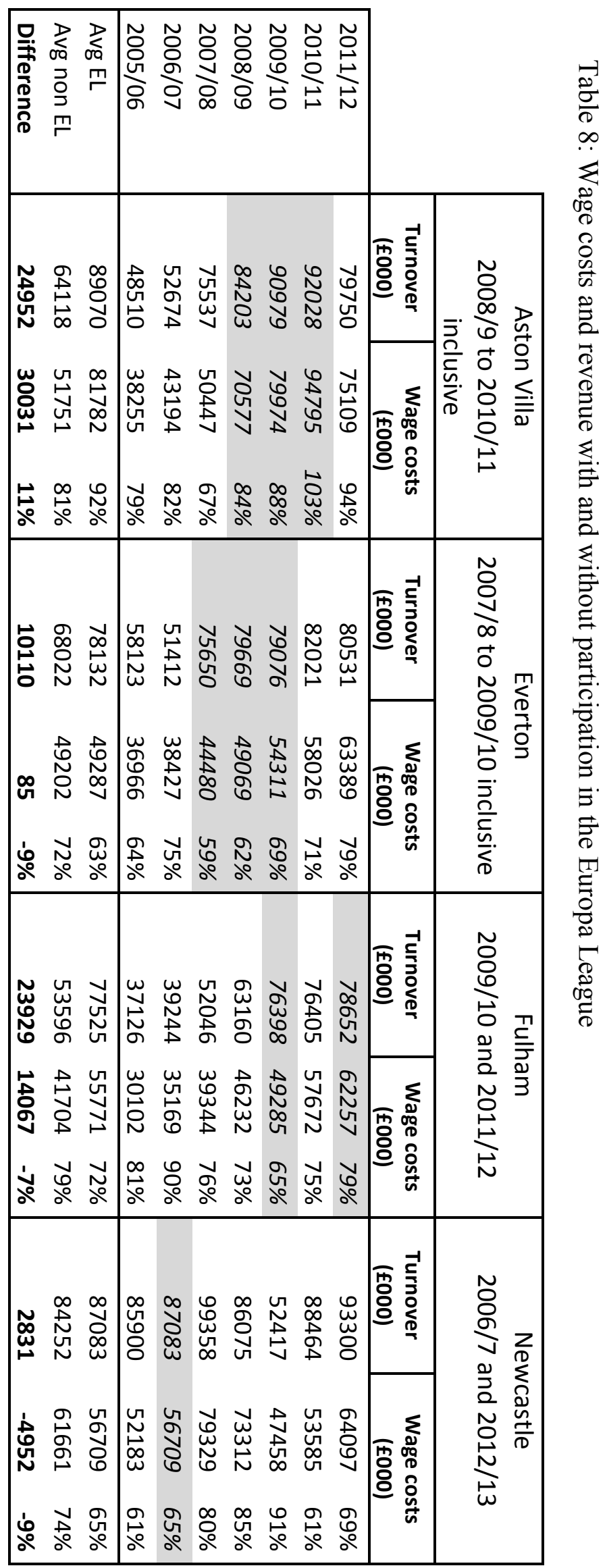




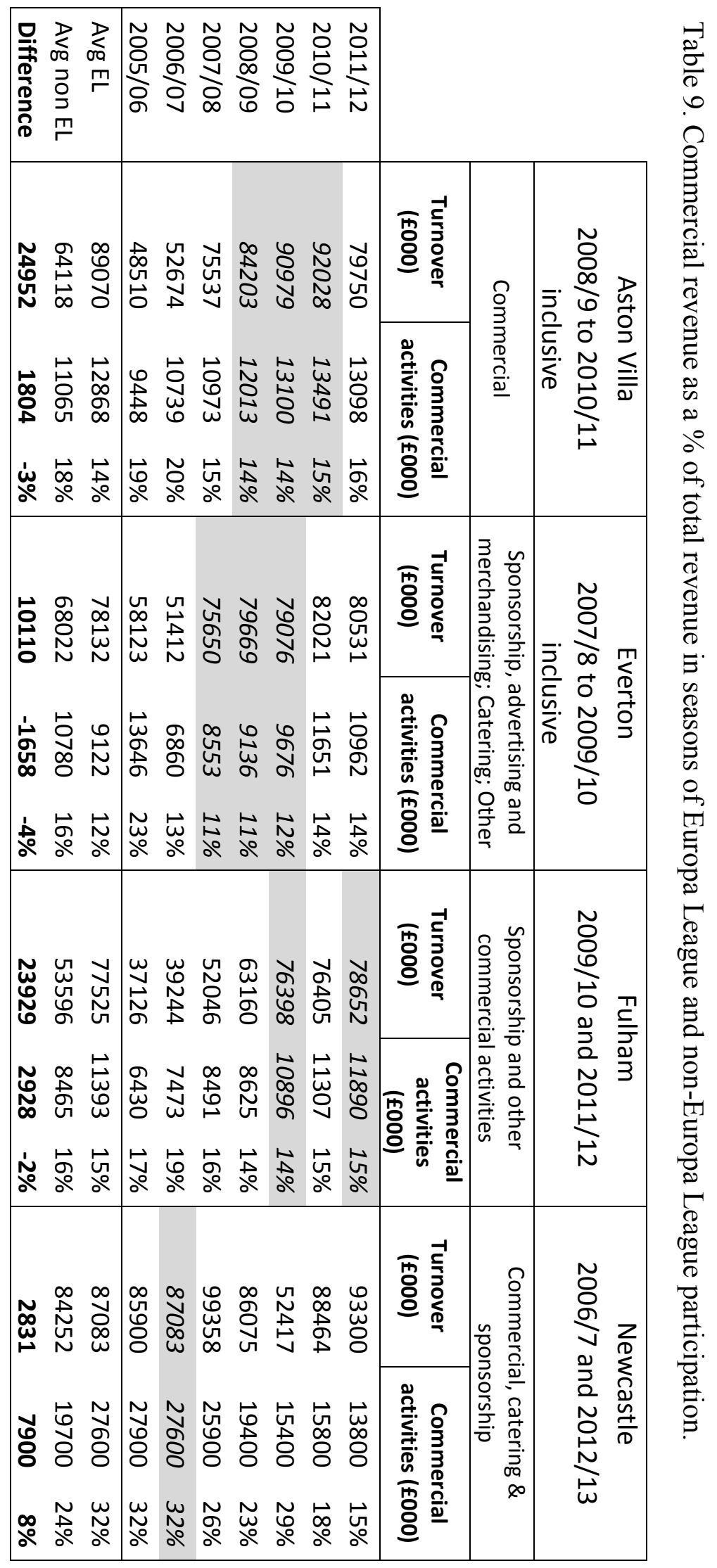




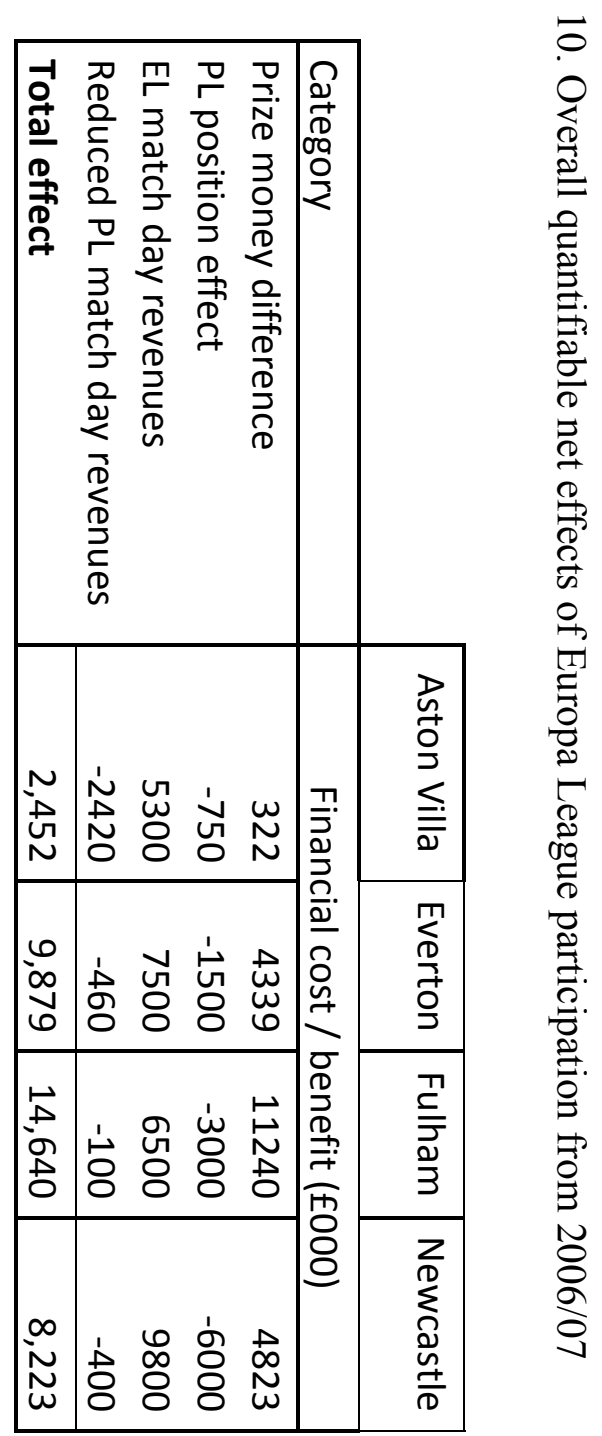




\section{Notes}

1. Martin, The 'Europeanization' of elite football, 349; King, Football fandom and post-national identity in the New Europe, 422; Giulianotti, Football: A Sociology of the Global Game.

2. Deloitte, Annual Review of Football Finance.

3. Martin, The 'Europeanization' of elite football, 356.

4. Deloitte, Deloitte Football Money League.

5. Key Note, Football clubs and finance market report.

6. Kennedy and Kennedy, Football supporters and the commercialisation of football: comparative responses across Europe, 328.

7. Calvin, 'BT Sport win rights to Champions League football: How TV's balance of power has been shifted by $£ 897 \mathrm{~m}$ deal that blows Sky Sports out the water'.

8. UEFA, 'UEFA Champions League: Distribution to Clubs 2012/13'.

9. Ibid.

10. Hamil and Walters, Financial performance in English professional football: 'an inconvenient truth'; Solberg and Haugen, European club football: why enormous revenues are not enough?; Storm and Nielsen, Soft budget constraints in professional football.

11. Geey, UEFA Fair Play Rules: A difficult balancing act.

12. Bosca et al., The two-track Europeanisation of football: EU-level pressures, transnational dynamics and their repercussions within different national contexts; Lago, Simmons and Szymanski, The financial crisis in European football; Ascari and Gagnepain, Spanish football; Frick and Prinz, Crisis? What crisis? Football in Germany; Barros, Portuguese football; Rezende, Dalmacio and Facure, Practice of corporate governance in football clubs.

13. Cuttler, 'Big Debate: Football's Finances'.

14. Deloitte, Deloitte Football Money League.

15. UEFA, 'Financial Report 2009/10'.

16. UEFA, 'Financial Fair Play Regulations are approved'.

17. Vopel, Do we really need financial fair play in European club football? An economic analysis.

18. Deloitte, Annual Review of Football Finance.

19. Ibid.

20. BBC Sport, 'Europa League winners will get Champions League place'.

21. Hamil and Walters, Financial performance in English professional football: 'an inconvenient truth'; Szymanski and Smith, The English Football Industry: profit, performance and industrial structure.

22. UEFA, 'Financial Report 2009/10'.

23. Deloitte, Annual Review of Football Finance.

24. Ibid.

25. Taylor, 'Manchester City and United should seize chance for Europa League glory'. 
26. Turner, 'Five reasons why the Europa League should be celebrated by all'.

27. Verheijen, Study on Recovery Days, 4.

28. Worldsoccertalk.com, 'The Premier League Prize Money Table'.

29. Gratton, The peculiar economics of English professional football, 11.

30. UEFA. 'About UEFA- Financial Reports'.

31. Deloitte, Annual Review of Football Finance, Years 2007-2013.

32. Rollin, Sky Sports Football Yearbook, Years 2005-2012.

33. Aston Villa Football Club Limited, Directors' report and financial statements; Everton Football Club Company Limited, Annual Report and Accounts; Fulham Football Leisure Limited, Annual Report; Newcastle United Limited, Report and Financial Statements.

34. Deloitte, Annual Review of Football Finance, Years 2007-2013.

35. UEFA. 'About UEFA- Financial Reports'.

36. Verheijen, Study on Recovery Days, 7.

37. Daily Mail, 'Arsenal revealed as most expensive day at football as fresh figures show how fans are being priced out of matches'.

38. Football.totalworlds.com, 'League Attendances'.

39. Guardian, 'How do ticket prices for the Premier League compare with Europe'?

40. Verheijen, Study on Recovery Days, 4.

41. Deloitte, Annual Review of Football Finance, Years 2007-2013.

42. Aston Villa Football Club Limited, Directors' report and financial statements; Everton Football Club Company Limited, Annual Report and Accounts; Fulham Football Leisure Limited, Annual Report; Newcastle United Limited, Report and Financial Statements.

43. Kennedy and Kennedy, Football supporters and the commercialisation of football: comparative responses across Europe, 337.

44. Bloomberg, 'Euro-British Pound Exchange rate'.

\section{References}

Ascari, G., and Gagnepain, P. 'Spanish football'. Journal of Sports Economics 7, no. 1 (2006): 76-89.

Aston Villa Football Club Limited, Directors' report and financial statements. Birmingham: Aston Villa, Years 2006-2012

Barros, P. S. 'Portuguese football'. Journal of Sports Economics, 7, no. 1 (2006): 96104.

BBC Sport, 'Europa League winners will get Champions League place'. BBC Sport. http://www.bbc.co.uk/sport/0/football/22640095

Bloomberg. 'Euro-British Pound Exchange rate'. Bloomberg.

http://www.bloomberg.com/quote/EURGBP:CUR. 
Bosca, J. E., Liern, V., Martinez, A., and Sala, R. 'The Spanish football crisis'. European Sport Management Quarterly 8, no. 2 (2008): 165-177.

Calvin, M. 'BT Sport win rights to Champions League football: How TV's balance of power has been shifted by $£ 897 \mathrm{~m}$ deal that blows Sky Sports out the water'. The Independent, November 10, 2013. http://www.independent.co.uk/sport/football/newsand-comment/bt-sport-win-rights-to-champions-league-football-how-tvs-balance-ofpower-has-been-shifted-by-897m-deal-that-blows-sky-sports-out-the-water8930769.html.

Cuttler, M. 'Big Debate: Football's Finances'. SportBusiness.com. http://m.sportbusiness.com/print-edition/big-debate/big-debate-football-finance

Daily Mail, 'Arsenal revealed as most expensive day at football as fresh figures show how fans are being priced out of matches' Daily Mail, http://www.dailymail.co.uk/sport/football/article-2219460/Big-rise-football-ticketprices-revealed--Arsenal-expensive.html

Deloitte. Annual Review of Football Finance. Manchester: Deloitte, 2007.

Deloitte. Annual Review of Football Finance. Manchester: Deloitte, 2008.

Deloitte. Annual Review of Football Finance. Manchester: Deloitte, 2009.

Deloitte. Annual Review of Football Finance. Manchester: Deloitte, 2010.

Deloitte. Annual Review of Football Finance. Manchester: Deloitte, 2011.

Deloitte. Annual Review of Football Finance. Manchester: Deloitte, 2012.

Deloitte. Deloitte Football Money League. Manchester: Deloitte, 2013.

ESPN (2013). Retrieved from the ESPN website:

http://espnfc.com/stats/attendance/ /league/eng.1/year/?cc=5739

Everton Football Club Company Limited, Annual Report and Accounts. Liverpool: Everton, Years 2006-2012.

Football.totalworlds.com, 'League Attendances'.

http://football.totalworlds.com/clubs/attendances/attendances.html. Accessed August 29, 2014.

Frick, B., and Prinz, J. 'Crisis? What crisis? Football in Germany'. Journal of Sports Economics 7, no. 1: 60-75.

Fulham Football Leisure Limited, Annual Report. London: Fulham, Years 2006-2012. 
Geey, D. UEFA Fair Play Rules: A difficult balancing act, Entertainment and Sport Law Journal 50 (2011).

Gratton, S. 'The peculiar economics of English professional football'. Soccer \& Society 1, no. 1 (2000): 11-28.

Guardian, 'How do ticket prices for the Premier League compare with Europe'? Guardian, http://www.theguardian.com/news/datablog/2013/jan/17/football-ticketprices-premier-league-europe. Accessed September 1, 2014.

Giulianotti, R. Football: A Sociology of the Global Game. Cambridge: Polity, 1999.

Hamil, S. and Walters, G. 'Financial performance in English professional football: 'an inconvenient truth”. Soccer \& Society 11, no.4 (2010): 354-372.

Kennedy, P. and Kennedy, D. 'Football supporters and the commercialisation of football: comparative responses across Europe'. Soccer \& Society 13, no.3 (2012): 327-340.

Key Note. Football clubs and finance market report. Richmond: Key Note, 2013.

King, A. 'Football fandom and post-national identity in the New Europe'. British Journal of Sociology 51, no. 3 (2000): 419-442.

Lago, U., Simmons, R. and Szymanski, S. 'The financial crisis in European football'. Journal of Sports Economics 7 (2006): 3-12.

Martin, P. 'The 'Europeanization' of elite football'. European Societies 7, no. 2 (2005): 349-368.

Newcastle United Limited, Report and Financial Statements. Newcastle: Newcastle, Years 2006-2012

Rezende, A. J., Dalmacio, F. Z., and Facure, C. E. F.' Practice of corporate governance in football clubs'. International Journal of Economics and Accounting 1, no. 4 (2010): 410-447.

Rollin, J. Sky Sports Football Yearbook. London: Headline, 2005.

Rollin, J. Sky Sports Football Yearbook. London: Headline, 2006.

Rollin, J. Sky Sports Football Yearbook. London: Headline, 2007.

Rollin, J. Sky Sports Football Yearbook. London: Headline, 2008.

Rollin, J. Sky Sports Football Yearbook. London: Headline, 2009.

Rollin, J. Sky Sports Football Yearbook. London: Headline, 2010.

Rollin, J. Sky Sports Football Yearbook. London: Headline, 2011. 
Rollin, J. Sky Sports Football Yearbook. London: Headline, 2012.

Solberg, H.A. and Haugen, K.K. 'European club football: why enormous revenues are not enough?' Sport in Society 13, no.2 (2010): 329 -343.

Storm, R.K. and Nielsen, K.N. 'Soft budget constraints in professional football'. European Sport Management Quarterly 12, no. 2 (2012): 183-201.

Szymanski, S. and Smith, R. 'The English Football Industry: profit, performance and industrial structure', International Review of Applied Economics 11, no. 1 (1997): 135-153.

Taylor, L. 'Manchester City and United should seize chance for Europa League glory', The Guardian, December 13, 2011.

http://www.theguardian.com/football/2011/dec/13/manchester-united-city-europaleague.

Turner, G. 'Five reasons why the Europa League should be celebrated by all'. The Guardian, April 4, 2013.

http://www.theguardian.com/football/blog/2013/apr/04/europa-league-five-reasonsto-watch

UEFA.'About UEFA- Financial Reports'. UEFA

http://www.uefa.org/documentlibrary/aboutuefa/index.html. Accessed August 29, 2014.

UEFA. 'Financial Report 2009/10'. UEFA.

http://www.uefa.org/MultimediaFiles/Download/uefaorg/General/01/61/07/93/16107 93_DOWNLOAD.pdf

UEFA. 'Financial Fair Play Regulations are approved'. UEFA. http://www.uefa.org/protecting-the-game/financial-fair-play/

UEFA. 'UEFA Champions League: Distribution to Clubs 2012/13'. UEFA. http://www.uefa.com/MultimediaFiles/Download/uefaorg/Finance/01/97/52/97/19752 97_DOWNLOAD.pdf

Verheijen, R. Study on Recovery Days. Amsterdam: World Football Academy, 2012.

Vopel, H., Do we really need financial fair play in European club football? An economic analysis. CESifo DICE Report 3/2011.

Worldsoccertalk.com, 'The Premier League Prize Money Table'. Worldsoccertalk.com. http://worldsoccertalk.com/2013/05/20/the-premier-leagueprize-money-table-see-how-many-millions-your-club-made/ 